\title{
PEMANFAATAN CAMPURAN RUMPUT LAUT DAN LIMBAH LIDAH BUAYA SEBAGAI FEED SUPPLEMENT SAPI BALI JANTAN
}

\author{
N. P. P. Wijayanti ${ }^{1 *}$ ), N. P. Mariani ${ }^{2}$, dan N. N. Suryani ${ }^{2}$ \\ ${ }^{1}$ Fakultas Kelautan dan Perikanan Universitas Udayana, Denpasar-Bali \\ ${ }^{2}$ Fakultas Peternakan Universitas Udayana, Denpasar-Bali \\ *) corresponding author: putri_wijayanti@unud.ac.id
}

\begin{abstract}
ABSTRAK
Rumput laut dan gulma rumput laut memiliki potensi besar sebagai salah satu sumber feed supplement pada ternak ruminansia. Sebuah penelitian telah dilaksanakan dengan tujuan untuk mendapatkan pengaruh pemberian limbah lidah buaya dan rumput laut sebagai feed supplement terhadap komposisi tubuh dan retensi nutrien sapi bali jantan. Percobaan menggunakan teknik ruang urea (urea dilution technique) terhadap 20 ekor sapi bali jantan dengan berat berkisar antara 191-232 kg. Rancangan acak kelompok (RAK) yang digunakan terdiri atas 5 perlakuan dan 4 kelompok berat badan sebagai ulangan. Perlakuan tersebut adalah: A (Jerami padi ad libitum $+2 \mathrm{~kg}$ konsentrat tanpa feed supplement), perlakuan B (Jerami padi ad libitum $+2 \mathrm{~kg}$ konsentrat $+150 \mathrm{~g}$ feed supplement), perlakuan C (Jerami padi ad libitum $+2,5 \mathrm{~kg}$ konsentrat +150 $\mathrm{g}$ feed supplement), perlakuan D (Jerami padi ad libitum $+3 \mathrm{~kg}$ konsentrat $+150 \mathrm{~g}$ feed supplement), dan perlakuan E (Jerami padi ad libitum $+3 \mathrm{~kg}$ konsentrat tanpa feed supplement). Peubah yang diukur kadar air tubuh (\%), kadar protein tubuh (\%), kadar lemak tubuh (\%), retensi protein (g/e/h), retensi lemak (g/e/h), dan retensi energi (kkal/e/h). Hasil penelitian menunjukkan bahwa pemberian 150 g campuran limbah lidah buaya dan rumput laut sebagai feed supplement pada sapi bali jantan memberikan hasil komposisi tubuh dan retensi nutrien terbaik pada pemberian konsentrat 2,5 kg. Dapat disimpulkan bahwa pemberian feed supplement campuran lidah buaya dan rumput laut dapat memperbaiki kualitas ransum yang kurang baik.
\end{abstract}

Kata kunci: feed supplement, lidah buaya, komposisi tubuh, rumput laut, sapi bali

\section{UTILIZATION OF SEAWEED MIXES WITH ALOE WASTE AS A FEED SUPPLEMENT FOR MALE BALI CATTLE}

\begin{abstract}
Seaweed and its weeds have a great potential as a source of feed supplements in ruminants. A study has been carried out with the aim to obtain the effect of seaweed and Aloe vera waste as feed supplements on body composition and nutrient retention of male Bali cattle. This research used urea dilution technique for 20 male Bali cattle with weights 191-232 kg. The randomized block design (RBD) used consisted of 5 treatments and 4 weight groups as replications. The treatments are: A (ad libitum rice straw $+2 \mathrm{~kg}$ concentrate without feed supplement), treatment B (ad libitum rice straw $+2 \mathrm{~kg}$ concentrate $+150 \mathrm{~g}$ feed supplement), treatment $\mathrm{C}$ (ad libitum rice straw $+2.5 \mathrm{~kg}$ concentrate $+150 \mathrm{~g}$ feed supplement), treatment $\mathrm{D}$ (ad libitum rice straw $+3 \mathrm{~kg}$ concentrate $+150 \mathrm{~g}$ feed supplement), and treatment $\mathrm{E}$ (ad libitum rice straw $+3 \mathrm{~kg}$ concentrate without feed supplement). Variables measured by content of body water (\%), body protein (\%), body fat (\%), dan retention of protein $(\mathrm{g} / \mathrm{e} / \mathrm{h})$, fat $(\mathrm{g} / \mathrm{e} / \mathrm{h})$, and energy $(\mathrm{kcal} / \mathrm{e} / \mathrm{h})$. The results showed that the treatment $150 \mathrm{~g}$ of Aloe vera waste and seaweed mixture as a feed supplement to bali cattle gave the best body composition and nutrient retention in $2.5 \mathrm{~kg}$ concentrate. It can be concluded that the provision of a feed supplement with a mixture of Aloe vera and seaweed can improve the quality of the feed.
\end{abstract}

Key words: feed supplement, aloe vera, body composition, seaweed, bali cattle 


\section{PENDAHULUAN}

Peningkatan produksi ternak ruminansia termasuk sapi bali harus diikuti oleh peningkatan penyediaan pakan hijauan yang cukup, baik jumlah maupun mutunya. Salah satu upaya untuk mengatasi kekurangan rumput ataupun hijauan pakan lainnya adalah memanfaatkan limbah pertanian seperti jerami padi sebagai pakan ternak. Pemanfaatan jerami padi sebagai pakan ternak mengalami beberapa kendala seperti nutrisinya yang rendah dibandingkan dengan rumput segar terutama dalam kandungan protein kasar dan mineral serta kecernaannya (Suryani et al., 2019). Kandungan protein kasar jerami padi rendah yaitu sekitar $3-5 \%$, serat kasarnya tinggi (>34\%), mineral yang rendah, ikatan lignoselulosanya kuat dan kecernaannya rendah (Sutrisno et al., 2006). Adanya keterbatasan pemanfaatan jerami padi, maka penggunaannya sebagai pakan ternak perlu mendapatkan sentuhan teknologi.

Salah satu upaya yang dapat dilakukan untuk memenuhi kebutuhan nutrisi ternak adalah dengan pemberian konsentrat yang ditambahkan dengan feed supplement. Feed supplement sering digunakan pada industri pakan ternak untuk memacu pertumbuhan maupun meningkatkan efisiensi penggunaan pakan yang pada akhirnya berujung pada peningkatan keuntungan. Feed supplement yang umum digunakan adalah probiotik, antibiotik, enzim, multivitamin mineral, dan sebagainya. Limbah lidah buaya adalah salah satu limbah pertanian yang mempunyai potensi untuk dijadikan sebagai feed supplement pada ransum sapi bali karena kaya akan nutrisi seperti karbohidrat, protein, vitamin, mineral dan lemak (Bani et al., 2016). Selain itu, rumput laut dan gulma rumput laut juga berpotensi dijadikan sebagai feed supplement. Rumput laut merupakan bahan makanan sumber gizi yaitu memiliki kandungan karbohidrat, protein, sedikit lemak, dan abu yang sebagian besar merupakan senyawa garam natrium dan kalium.

Pada fase pertumbuhan, sapi sangat rentan terhadap ketidakseimbangan bakteri enterik, yang menyebabkan pencernaan dan penyerapan nutrisi dan infeksi saluran pencernaan menjadi tidak efisien sehingga mengakibatkan pertumbuhan yang buruk dan mortalitas yang tinggi dan sekitar 30\% kematian karena infeksi gastrointestinal. Untuk mengatasi kondisi ini, pemberian suplemen pada pakan yang bersifat antibiotik untuk mengurangi bakteri patogen sehingga meningkatkan aktivitas rumen menjadi sangat penting (Yadav et al., 2017). Dengan demikian, nutrisi pakan yang dikonsumsi dapat disimpan di dalam tubuh ternak yang selanjutnya diukur dalam bentuk retensi nutrien pada ternak itu sendiri.

Cara penentuan komposisi tubuh hewan yang paling tepat adalah dengan melakukan pemotongan terhadap hewan tersebut kemudian menggiling seluruh bagian tubuhnya. Namun demikian cara pengukuran komposisi tubuh secara langsung seperti tersebut memerlukan tenaga yang banyak, waktu yang lama dan biaya yang mahal, terutama untuk ternak besar. Oleh karena itu, diperlukan pendugaan komposisi tubuh hewan secara tidak langsung seperti teknik perunutan atau teknik pengukuran distribusi ruang urea (Bartle et al., 1983, dan Rule et al., 1986).

Penggunaan larutan urea sebagai perunut didasarkan atas kenyataan bahwa molekul urea dapat bercampur merata dengan cepat bersama cairan tubuh dalam waktu relatif singkat yaitu 12 menit pada sapi (Rule et al., 1986). Selain itu urea tidak beracun, bukan merupakan senyawa asing bagi tubuh dan tidak menimbulkan gangguan fisiologi bagi hewan, sehingga hasilnya mendekati kebenaran dan mudah pelaksanaannya. Berdasarkan pentingnya penentuan komposisi tubuh hewan tersebut, dan masih terbatasnya informasi tentang komposisi tubuh dan retensi nutrien sapi bali jantan, maka perlu diadakan penelitian mengenai pengaruh pemberian limbah lidah buaya dan rumput laut sebagai feed supplement terhadap komposisi tubuh dan retensi nutrien sapi bali jantan yang diukur dengan teknik ruang urea (urea dilution technique).

\section{MATERI DAN METODE}

Penelitian ini dilaksanakan selama 3 bulan yang bertempat di Kelompok Tani Ternak Nandi Abian di Desa Abian Base, Kabupaten Gianyar. Sapi yang digunakan adalah sapi bali jantan berjumlah 20 ekor dengan kisaran berat 191-232 kg. Rancangan percobaan yang digunakan dalam penelitian adalah rancangan acak kelompok (RAK) terdiri dari 5 perlakuan dengan 4 kelompok berat badan sebagai ulangan. Variabel yang diamati pada penelitian ini adalah komposisi tubuh yaitu kadar air tubuh, lemak tubuh, protein tubuh, dan retensi nutrien yaitu retensi lemak, retensi protein dan retensi energi.

\section{Penentuan Komposisi Tubuh Ternak}

Penentuan komposisi tubuh ternak ditentukan dengan cara sebaran (distribusi) ruang urea (Rule et al., 1986). Ruang urea dihitung dengan rumus :

$$
\mathrm{RU}(\%)=\frac{\mathrm{U}}{\Delta \mathrm{U} \times 10 \times \mathrm{W}} \text { (Rule, et al., 1986) }
$$

$$
\begin{aligned}
& \text { Dimana: } \\
& \mathrm{RU}=\text { Ruang Urea } \\
& \mathrm{U}=\text { Jumlah urea yang diinfusikan } \\
& \Delta \mathrm{U}=\text { Perubahan kadar urea darah } \\
& \mathrm{W}=\text { Berat tubuh }
\end{aligned}
$$


Nilai RU yang diperoleh kemudian digunakan untuk menduga komposisi tubuh yaitu kadar air, protein, dan lemak tubuh. Persamaan yang digunakan untuk menduga komposisi tubuh adalah :

Air Tubuh Kosong (\%) $=59,1+0,22 \mathrm{RU}-0,04 \mathrm{~W}$

Protein Tubuh (\%) $=16,5+0,07 \mathrm{RU}+0,001 \mathrm{~W}$

Lemak Tubuh (\%) $=-0,69+0,89 \times$ Lemak Tubuh (\%) dari RU (Sukarini, 2000) Lemak Tubuh (\%) = $-0,69+0,89 \times$ Lemak Tubuh (\%) dari RU (Sukarini, 2000).

\section{Retensi Nutrien}

Retensi Protein dapat dihitung dengan rumus :

Retensi Protein $=\underline{\% \text { Protein } \mathrm{x} \text { Pertambahan Berat Badan }}$ 100

Retensi Lemak dapat dihitung dengan rumus :

Retensi Lemak $=\frac{\text { \% Lemak x Pertambahan Berat Badan }}{100}$

Hasil pengukuran retensi lemak dan protein dapat dikonversi menjadi retensi energi, dengan ketentuan retensi $1 \mathrm{~g}$ protein tubuh mengandung $5 \mathrm{Kkal}$ dan retensi $1 \mathrm{~g}$ lemak tubuh mengandung $9 \mathrm{Kkal}$ (Ørskov dan Ryle, 1990).

Retensi Energi (RE) dapat ditentukan dengan rumus :

$\mathrm{RE}=($ Retensi Protein $\times 5)+($ Retensi Lemak $\times 9)$

Data yang diperoleh dianalisis dengan sidik ragam. Bila nilai rata-rata perlakuan berbeda nyata pada masing-masing peubah respons, maka analisis dilanjutkan dengan Uji Duncan pada taraf $5 \%$ (Steel dan Torrie, 1989).

\section{HASIL DAN PEMBAHASAN}

Kadar air tubuh sapi yang mendapat perlakuan A adalah 49,09\%, perlakuan B sebesar 48,87\%, perlakuan C sebesar 48,94\%, perlakuan D sebesar 48,62\%, dan perlakuan E yaitu 48,36\% (Tabel 1). Suplementasi $150 \mathrm{~g}$ feed supplement baik pada perlakuan $\mathrm{B}$, perlakuan $\mathrm{C}$, dan perlakuan $\mathrm{D}$ tidak berpengaruh terhadap kadar air tubuh sapi bali jantan. Pada perlakuan A dan E yaitu pemberian 2 dan $3 \mathrm{~kg}$ konsentrat tanpa suplementasi feed supplement kadar air tubuhnya berbeda nyata. Hal ini disebabkan karena berat badan akhir pada perlakuan B, C, dan $\mathrm{D}$ berbeda tidak nyata dan berat badan akhir pada perlakuan A dan $\mathrm{E}$ berbeda nyata. Ini membuktikan bahwa berat badan akhir berbanding terbalik dengan kadar air tubuh. Semakin tinggi berat badan akhir maka kadar air tubuh semakin rendah. Hal ini dapat terlihat pada perlakuan E yang kadar air tubuhnya paling rendah dan berat badan akhirnya paling tinggi diantara semua perlakuan. Kadar air tubuh normal sapi Nollero jantan pertumbuhan berada pada kisaran $57,27-68,78 \%$ (Silva et at., 2017) dan kadar air tubuh sapi bali betina lepas sapih adalah 54,11-54,23\% (Rahman et al., 2017). Sementara hasil penelitian ini kadar air tubuh berkisar antara 48,36-49,09\%. Hasil kadar air tubuh yang didapat tidak jauh berbeda dengan kadar air tubuh sapi bali betina pada hasil penelitian Sukarini (2000) yaitu 48,51-49,14\%.

Ransum yang disuplementasi feed supplement tidak berpengaruh terhadap kadar protein tubuh sapi bali jantan. Kadar protein tubuh yang diperoleh berkisar antara 16,75-16,77\% (Tabel 1), lebih tinggi dari hasil yang diperoleh Sukarini (2000) pada sapi bali betina yaitu berkisar antara $15,42-15,61 \%$. Sementara Silva et al. (2017) melaporkan bahwa kadar protein tubuh sapi Nellore jantan berkisar antara $13,52-21,66 \%$. Kadar protein tubuh dapat dikatakan tetap dan persentasenya tidak dipengaruhi oleh umur dan makanan segera setelah kedewasaan tercapai. Menurut Purnomoadi et al. (2008) bahwa perubahan protein tubuh mengalami penurunan seiring bertambahnya umur. Namun kadar protein tubuh lebih dipengaruhi oleh faktor keturunan dan jenis hewan, dikarenakan zat-zat protein banyak terkandung di dalam otot dan tulang yang merupakan komponen penyusun sebagian besar tubuh ternak.

Kadar lemak tubuh sapi bali jantan yang disuplementasi feed supplement yaitu perlakuan B, $\mathrm{C}$, dan $\mathrm{D}$ tidak berbeda nyata dibandingkan dengan perlakuan yang tidak disuplementasi feed supplement yaitu perlakuan A dan E. Kadar lemak tubuh sapi bali jantan pada perlakuan E nyata lebih tinggi dibandingkan dengan perlakuan A. Pada perlakuan $\mathrm{E}$, berat badan yang diperoleh paling tinggi, demikian juga terhadap kadar lemak tubuhnya. Sementara pada perlakuan B, C, dan D kadar lemak tubuhnya tidak berbeda nyata. Ini disebabkan karena berat badan akhir sapi bali jantan pada perlakuan B, C, dan D secara statistik tidak berbeda. Hasil percobaan ini mengindikasikan bahwa berat badan berhubungan dengan komposisi tubuh sapi. Kadar lemak tubuh sangat erat hubungannya dengan retensi lemak pada ternak. Kisaran kadar lemak tubuh dari hasil percobaan yaitu $27,80-28,62 \%$ lebih rendah dari kisaran yang diperoleh oleh Sukarini (2000) yaitu 28,92-29,08\%. Perbedaan ini barangkali disebabkan karena komposisi bahan makanan yang dipakai berbeda dan berat badan ternak berbeda.

Suplementasi feed supplement dapat meningkatkan secara nyata retensi protein pada sapi bali jantan yang mendapat perlakuan $\mathrm{B}, \mathrm{C}$, dan $\mathrm{D}$, dimana retensi tertinggi pada ransum perlakuan $\mathrm{D}$ diikuti perlakuan C dan B masing-masing 108,95; 100,87; dan 91,18 $\mathrm{g} / \mathrm{e} / \mathrm{h}$ (Tabel 1). Hal ini dapat dijelaskan bahwa retensi 
Tabel 1. Komposisi Tubuh dan Retensi Nutrien

\begin{tabular}{|c|c|c|c|c|c|c|}
\hline \multirow{2}{*}{ Peubah } & \multicolumn{5}{|c|}{ Perlakuan $^{1}$} & \multirow{2}{*}{ SEM 3} \\
\hline & A & $\mathrm{B}$ & $\mathrm{C}$ & $\mathrm{D}$ & $\mathrm{E}$ & \\
\hline Kadar Air Tubuh (\%) & $49,09^{\mathrm{a} 2}$ & $48,87^{\mathrm{ab}}$ & $48,94^{\mathrm{ab}}$ & $48,62^{\mathrm{ab}}$ & $48,36^{b}$ & 0,184 \\
\hline Protein Tubuh (\%) & $16,75^{\mathrm{a}}$ & $16,76^{\mathrm{a}}$ & $16,76^{\mathrm{a}}$ & $16,76^{\mathrm{a}}$ & $16,77^{\mathrm{a}}$ & 0,004 \\
\hline Lemak Tubuh (\%) & $27,80^{\mathrm{a}}$ & $28,05^{\mathrm{ab}}$ & $27,97^{\mathrm{ab}}$ & $28,32^{\mathrm{ab}}$ & $28,62^{b}$ & 0,206 \\
\hline Retensi Protein (g/e/h) & $83,34^{\mathrm{a}}$ & $91,18^{\mathrm{a}}$ & $100,87^{\mathrm{b}}$ & $108,95^{\mathrm{bc}}$ & $110,41^{c}$ & 2,425 \\
\hline Retensi Lemak (g/e/h) & $138,62^{\mathrm{a}}$ & $158,86^{\mathrm{ab}}$ & $167,61^{\mathrm{ab}}$ & $181,94^{b}$ & $188,87^{b}$ & 10,965 \\
\hline Retensi Energi (Kkal/e/h) & $1664,29^{\mathrm{a}}$ & $1885,60^{a b}$ & $2021,81^{a b}$ & $2182,19^{b}$ & $2251,93^{b}$ & 105,646 \\
\hline
\end{tabular}

Keterangan :

1. Perlakuan A : Jerami padi ad libitum $+2 \mathrm{~kg}$ konsentrat tanpa feed supplement

Perlakuan B : Jerami padi ad libitum $+2 \mathrm{~kg}$ konsentrat $+150 \mathrm{~g}$ feed supplement

Perlakuan C : Jerami padi ad libitum $+2,5 \mathrm{~kg}$ konsentrat $+150 \mathrm{~g}$ feed supplement

Perlakuan D : Jerami padi ad libitum $+3 \mathrm{~kg}$ konsentrat $+150 \mathrm{~g}$ feed supplement

Perlakuan E : Jerami padi ad libitum + $3 \mathrm{~kg}$ konsentrat tanpa feed supplement

2. Angka yang diikuti huruf superscrip yang tidak sama pada baris yang sama, berbeda nyata $(P<0,05)$.

3. SEM (Standard Error of The Treatment Mean)

protein yang lebih tinggi disebabkan oleh konsumsi protein kasar ransum yang meningkat akibat peningkatan level konsentrat sehingga kadar protein ransum yang dikonsumsi lebih tinggi dari perlakuan lainnya. Semakin tinggi kandungan protein pakan dan diikuti dengan kecernaan protein yang tinggi, maka retensi protein dalam tubuh juga meningkat. Protein pakan di dalam rumen akan didegradasi oleh bakteri proteolitik menjadi oligopeptida dan selanjutnya dihidrolisa menjadi asam amino. Sebagian asam amino diserap melalui dinding rumen dan sebagian lagi dideaminasi menjadi asam alfa keto yang menghasilkan amonia, volatile fatty acids (VFA) dan $\mathrm{CO}_{2}$. Amonia $\left(\mathrm{NH}_{3}\right)$ merupakan produk utama dari proses deaminasi asam amino dan kecukupannya dalam rumen untuk memasok sebagian besar nitrogen untuk sintesis protein oleh $\pm 82 \%$ spesies mikroba rumen (Park et al., 2018).

Retensi protein pada penelitian ini lebih tinggi dibanding retensi protein sapi bali jantan yang mendapat ransum mengandung protein $15,42 \%$ dan GE 4,02 Mcal/kg DM yaitu 93,49 g/e/hari (Mariani et al., 2015). Retensi protein merupakan keseimbangan antara protein yang dapat dikonsumsi dengan protein yang keluar lewat feses serta indigenous protein.

Hasil retensi lemak pada sapi bali jantan pada penelitian ini berkisar 138,62-188,87 g/e/h. Retensi lemak yang disuplementasi feed supplement cenderung mengalami peningkatan pada perlakuan B, C, dan D yaitu 158,86; 167,61; dan 181,94 g/e/h. Peningkatan retensi lemak erat kaitannya dengan meningkatnya konsumsi ransum termasuk konsumsi energi. Konsumsi ransum dan konsumsi energi meningkat tetapi tidak berbeda nyata dengan semua perlakuan. Pencernaan karbohidrat dari bahan yang mudah didegradasi akan menghasilkan VFA, yang digunakan oleh mikroba rumen pada awal fermentasi sebagai kerangka karbon protein tubuhnya dan pada akhir fermentasi digunakan sebagai sumber energi untuk ternak. Menurut Cakra (2013) retensi lemak berkorelasi positif dengan energi termetabolis, sehingga semakin tinggi energi termetabolis maka retensi lemak akan tinggi pula. Kadar lemak tubuh cenderung naik dengan bertambahnya berat badan dan kadar air cenderung menurun.

Beberapa faktor yang mempengaruhi kecepatan retensi lemak dalam jaringan adipose adalah genotipe dan adanya konsentrat dalam ransum. Selanjutnya dinyatakan pula bahwa terjadinya retensi lemak akibat proses metabolisme atau sebagai hasil dari proses anabolisme yang melampaui hasil proses katabolisme. Lipogenesis dan asam lemak rantai panjang (seperti linoleik, linolenik, dan palmitat), dipakai untuk anabolisme. Sedangkan lipolisis dan oksidasi berperan dalam katabolisme. Karbohidrat dimetabolisme menjadi unit-unit glukose dan glukose dibutuhkan untuk membentuk asam lemak rantai panjang. Sedangkan propionat yang merupakan bagian dari VFA, mempunyai peranan penting dalam sintesis glukose (Park et al., 2018).

Meningkatnya retensi energi sebagai akibat dari meningkatnya sintesis protein tubuh, karena energi sangat diperlukan sebagai kerangka karbon oleh asam amino untuk membentuk protein tubuhnya. Meningkatnya protein mikrobial akan meningkat pula retensi protein dan energi dalam tubuh. Adanya peningkatan retensi protein, lemak dan energi berarti sejalan dengan adanya peningkatan pertumbuhan.

\section{SIMPULAN DAN SARAN}

Berdasarkan hasil penelitian, dapat disimpulkan bahwa pemberian $150 \mathrm{~g}$ campuran limbah lidah buaya dan rumput laut sebagai feed supplement pada sapi bali jantan memberikan hasil komposisi tubuh dan retensi nutrien terbaik pada pemberian konsentrat 2,5 kg. Dengan demikian pemberian feed supplement campuran lidah buaya dan rumput laut dapat memperbaiki kualitas ransum yang kurang baik. 


\section{DAFTAR PUSTAKA}

Bani, P., Grossi, P., Lucini, L., Pellizzoni, M., Minuti, A and Trevisi, E. 2016. Administration of Aloe arborescens homogenate to cattle: interaction with rumen fermentation and gut absorption of aloin. Italian J. of Anim. Sci. 15(2): 233-240.

Bartle. S. J., J. R. Males and R. L. Preston. 1983. Evaluation of Urea Dilution as an Estimation of Body Composition in Mature Cows. J. Anim. Sci. 56: 410-417.

Cakra, I G. L. O. 2013. Kinerja Rumen dan Pertumbuhan Ternak Kambing yang diberikan Pakan Konsentrat Mengandung Urea Kapur dan Ubi Kayu. Disertasi. Denpasar: Program Pascasarjana Universitas Udayana.

Ørskov, E. R. and Ryle. 1990. Energy Nutrition in Ruminant. Elsevier Applied Science. London.

Park, S. J, S. H. Beak, D. J. S. Jung, S. Y. Kim, H. I. Jeong, M. Y. Piao, H. J Kang, D. M. Fassah, S. W. Na, S. P. Yoo, M. Baik. 2018. Genetic, management, and nutritional factors affecting intramuscular fat deposition in beef cattle - A review. Asian-Australas J Anim Sci 31(7): 10431061.

Purnomoadi, A., B. M. Alviani, E. Purbowati, dan Soeparno. 2008. Body composition of ongole crossbred growing bull under intensive feeding management. J. Indon. Trop. 32 (1):1-5.

Mariani, N. P., I G. Mahardika, S. Putra, dan I. B. G. Partama. 2015. Penentuan keseimbangan protein dan energi ransum sapi bali jantan. J. Peternakan Indonesia. 17(1): 46-53.

Rahman, A., I W. Suarna, dan N. N. Suryani. 2017. Komposisi tubuh sapi bali betina lepas sapih yang mendapat ransum dengan kandungan protein dan energi berbeda. Peternakan Tropika 5 (3): $480-488$.
Rule, D. C., R. N. Arnol., E. J. Hentges, and D. C. Beitz. 1986. Evaluation of urea Dilution as a Technique For estimating Body Composition of Beef Steers In Vivo. Validations of Published Equations and Comparison with Chemical Composition. J. Anim. Sci. 63: 1935-1948.

Silva, L. H. O., S. F. M. Bonilha, R. H. Branco, J. N. dos S. G. Cyrillo, dan M. E. Z. Mercadante. 2017. Development and evaluation of models to estimate body chemical composition of young Nellore bulls. R. Bras. Zootec. 46 (2):156-166.

Steel, R. G. D and J. H. Torrie. 1989. Principles and Procedures of Statistic. McGraw-Hill Book Co. Inc. New York.

Sukarini, I. A. M. 200o. Peningkatan Kinerja Laktasi Sapi Bali (Bibos banteng) Beranak Pertama Melalui Perbaikan Mutu Pakan. Disertasi. Program Pascasarjana Institut Pertanian Bogor. Bogor.

Suryani, N. N., I G. Mahardika, I W. Suarna, and N. P. Sarini 2019. Increased Gliricidia sepium in ration containing rice straw on rumen fermentation and microbial protein synthesis of indigenous bali cattle. Advances in Animal and Veterinary Sciences, 7: 193-199. DOI: http://dx.doi. org/10.17582/journal.aavs/2019/7.3.193.199

Sutardi, T. 1980. Landasan Ilmu Nutrisi. Jilid I Dept. Ilmu Makanan Ternak. Institut Pertanian Bogor, Bogor.

Sutrisno, C. I., Sulistyanto, Widyati S., Nurwanto., Mukodiningsih, S., Surahmanto, dan Tristiarti. 2006. Peningkatan Jerami Padi sebagai Pakan. Available from: URL: http//: www.dikti.org/ p3m/ abstrakHB/ AbstrakHBO5. pdf.

Yadav, A. K., Kumar, S., Barman, R.S.D., Varma, R.K. and Jha, D. K. 2017. The Effect of Aloe vera on Growth and Body measurement traits in cross bred calf. Res J. Chem. Environ. Sci. 5 (4): 37-44. 